\title{
İnşaat endüstrisinde özel sektörde çalışan inşaat mühendislerini demotive eden faktörler
}

\author{
Gülden GÜMÜŞBURUN AYALP ${ }^{1, *}$, Fatma ARSLAN ${ }^{2}$ \\ ${ }^{1}$ Toros Üniversitesi, Güzel Sanatlar, Tasarım ve Mimarlı Fakültesi, Mimarlık Bölümü, Mersin \\ ${ }^{2}$ Evşen Konukoğlu Mimarlık, Gaziantep \\ Geliş Tarihi (Recived Date): 06.04.2017 \\ Kabul Tarihi (Accepted Date): 22.06.2017
}

\section{Özet}

İşaat işleri karmaşık, dinamik ve belirsizlikleri fazla olan bir üretim türüdür. Yapı üretim sürecinin etkin ve verimli olabilmesi için iyi motive olmuş çalışanlara ihtiyaç duyulmaktadır. Çalışanların amaçlarına ulaşması sürecinde kendilerinde tatminsizlik ve memnuniyetsizlik yaratan durumların varlığından ortaya çıkan "demotivasyon" kavramı önemli bir hale gelmektedir. Bu kapsamda sektör çalışanlarını demotive eden faktörlerin bilinmesi önem arz etmektedir. Bu noktadan hareketle, bu çalışmada Türk inşaat sektöründe özel sektörde çalışan inşaat mühendislerini demotive eden faktörlerin belirlenmesi amaçlanmıştır. Bu çerçevede, yapılan literatür araştırması sonucunda inşaat mühendislerini etkileyebilecek 69 demotivasyon kriteri belirlenerek hazırlanan anket ile ülke genelindeki 118 inşaat mühendisinden veri toplanmıştır. Toplanan verilere çeşitli istatistiksel analizler uygulanarak inşaat mühendislerini demotive eden faktörler belirlenmiştir.

Anahtar Kelimeler: Demotivasyon faktörleri, inşaat mühendisi, inşaat sektörü, proje ve yapım yönetimi.

\section{Analysis of civil engineers' demotivating factors in private sector}

\begin{abstract}
Construction is a complicated and dynamic production type that has lots of uncertainties. Well-motivated employees are needed for effective and efficient construction. During the employees' reaching their goals on themselves "demotivation" becomes significant, which emerges from the presence of the situations creating dissatisfaction and discontentedness. With this context, identifying the demotivation

\footnotetext{
* Gülden GÜMÜŞBURUN AYALP, mimargulden@gmail.com, http://orcid.org/0000-0002-7989-5569

Fatma ARSLAN, mmr.fatma.arslan@gmail.com, http://orcid.org/0000-0002-1322-4295
} 
factors of employees is important. From this point of view, in this study, the determination of the factors demotivating civil engineers working in Turkish private construction industry is aimed. Within this scope, data were collected from a questionnaire prepared by being determined 69 demotivation criteria which will influence civil engineers and from 118 civil engineers throughout the country who are employed in private construction industry, as a result of a literature research made comprehensively. Factors demotivating civil engineers are respectively determined by carrying out several statistical analyses to the data collected.

Keywords: Demotivating factors, civil engineer, construction industry, construction management.

\section{Giriş}

Organizasyonların hedeflerine ulaşabilmeleri ve başarılı olabilmeleri, kaynaklarını etkin ve verimli şekilde kullanmalarına bağlıdır. Bu kaynaklar ele alındığında yapı üretim süreci girdilerden biri olan insan kaynağının, önemli bir değişken olarak ele alınması ve bu doğrultuda değerlendirilmesi gerekmektedir. Ancak örgütlerin yönetmesi en güç öğesi de farklılıkları ve değişkenlikleri ile yine insan kaynağıdır. Bu nedenle, organizasyon içindeki çalışanları neyin motive ya da demotive ettiğin uzun yıllardan bu yana belirlenmeye çalışılmaktadır.

Ritchie ve Martin [1], bir yöneticinin görevinin çalışanları neyin demotive ettiğini belirlemek yerine, önemli olanın çalışanları neyin motive ettiğini bulmak olduğunu savunmuşlardır. Gorham ve Christophel [2] ise motive olmama durumunun demotivasyon kavramı ile aynı olduğu yönünde görüş bildirmişlerdir.

Diğer yandan farklı araştırmacılar [3] demotivasyon ile motive olmama durumunun iki farlı kavram olduğunu belirtmişlerdir.

Literatürde motivasyon ile ilgili yapılmış ilk çalışmalara 1940'lı yıllarda rastlanmaktadır [4]. İnşaat sektöründe ise motivasyon ile ilgili yapılmış olan çalışmalara 1970'lerin başlarında rastlanmakta ve günümüze kadar devam ettiği görülmektedir [5-12]. Bu çalışmaların hemen hemen hepsi inşaat sektörü çalışanlarını motive eden faktörler üzerine odaklanmışlardır. Literatürde inşaat sektörü çalışanlarını demotive eden faktörler üzerine yapılmış çalışma sayısının azlığı dikkat çekmektedir. Bu çalışmaların ilki 2013 yılında Oyedele [13] tarafından yapılmıştır. Araştırmacı mimarları demotive eden faktörleri belirlemek için yaptığı literatür taraması sonucunda elde ettiği 43 adet demotivasyon kriteri ile çeşitli analizler yapmış ve mimarları demotive eden yedi adet demotivasyon faktörü belirlemiştir. Konuyla ilgili ülkemizde yapılan çalışmalardan birisinde ise mimari tasarım bürolarında çalışan mimarların mesleki tükenmişlik düzeylerini etkileyen demotivasyon faktörleri araştırılmıştır [14]. Literatürde inşaat mühendisliği alanında demotivasyonla ilgili yapılmış yalnızca bir çalışmaya rastlanmaktadır [3]. Bu çalışmada ise araştırmacılar inşaat mühendisliği projelerinin verimliliğini etkileyen demotivasyon faktörleri üzerinde çalışmışlardır. Yapılmış araştırmalardan da görüldüğü üzere inşaat sektöründe hem mimarlık hem de inşaat mühendisliği disiplinlerinde demotivasyon ile ilgili yapılmış çalışmaların sayısı oldukça azdır. Oysaki yapı üretimi sürecinde ortaya çıkabilecek güçlüklerin ve 
çatışmaların en az seviyede olması için bu sürece katkı sağlayan her bir katılımcıyı motive ve demotive eden faktörlerin bilinmesi önem arz etmektedir.

Yapı üretim sürecinde pek çok kaynak bulunmaktadır. Bunlardan birisi insan olup, yönetilmesi ve kontrol edilmesi en güç kaynakların başında gelmektedir. Bu nedenle organizasyon içindeki çalışanları neyin motive ya da demotive ettiği uzun yıllardan bu yana belirlenmeye çalışılmaktadır. Organizasyon içindeki yöneticiler ve işverenler motive olmuş çalışanların kendilerine ve organizasyonlarına finansal avantajlar sağladığının farkına varmaya başlamışlardır [15]. Bu durumun tam tersi ele alındığında ise, demotive olan çalışanların işlerinde daha az çaba gösterdikleri, sorumluluklardan uzak durdukları, düşük kalitede iş yaptıkları dikkat çekmiştir. Buna ek olarak demotive olmuş çalışanlar takım ruhunu bozmakta ve diğer ekip üyelerinin de işlerine harcadıkları çabaların azalmasına neden olmaktadır $[16,17]$.

İnşaat sektörü kendisine bağlı iki yüzden fazla alt sektörün ürettiği mal ve hizmete talep yaratan konumda olup, bu yaygın etki, sektörün "ekonominin lokomotifi" olma özelliğinin en temel göstergesidir. İnşaat sektörünün Gayri Safi Yurt İçi Hasıla içerisindeki payının önemli bir orana sahip olduğu bilinmektedir. 2016 yılının birinci çeyreğinde sektörü oluşturan faaliyetlerin toplam katma değeri 975 milyar 156 milyon TL olup, bu veriler ile sektörün Gayri Safi Milli Hasıla (GSMH) içindeki payı \%3,1 düzeyinde olmuştur [18]. İnşaat yatırımlarında gerek kamu sektörü harcamaları gerekse özel sektör harcamaları önemli yer tutmaktadır. 2016 yılı verilerine göre Gayri Safi Sabit Sermaye oluşumu içerisinde kamu inşaat harcamaları \%1,6 oranında büyürken, özel sektör inşaat harcamaları ise $\% 8,2$ oranında artarak pozitif bir büyüme göstermiştir [18]. Bu verilerden de anlaşılacağı üzere inşaat endüstrisinde özel sektör yatırımları önemli yer tutmaktadır. Özel sektör inşaatları ve kamu sektörü inşaatlarının pek çok ortak paydası bulunmakla birlikte birbirlerinden farklılık gösteren özellikleri de mevcuttur. $\mathrm{Bu}$ farklılaşmalar bu sektörlerde çalışan proje paydaşlarının çalışma koşullarını da farklılaştırmaktadır.

Yap1 üretim sürecinde tasarımı tamamlanan projelerin beklenildiği şekilde hayata geçirilme sürecinde önemli rol oynayan inşaat mühendisleri de çalıştıkları sektörün özelliklerinden olumlu ya da olumsuz şekilde etkilenmektedirler. İnşaat işlerinin gerçekleştirilme sürecinde, proje ekiplerinin içinde yer alan her bir çalışan, ekip içi zayıf ilişkiler, kalitesiz veya yetersiz malzeme, kalifiye olmayan işçi gibi kendilerini demotive edebilecek pek çok problemle karşılaşmaktadırlar [3].

$\mathrm{Bu}$ nedenle bu çalışmada özel sektörde çalışan inşaat mühendislerini demotive eden kriterlerin belirlenmesi, belirlenen bu kriterlerle çeşitli demografik özellikler arasında ilişki olup olmadığının belirlenmesi, inşaat mühendislerini en çok ve en az demotive eden kriterlerin neler olduğunun tespit edilmesi ve son olarak demotivasyon faktörlerinin belirlenmesi amaçlanmıştır. $\mathrm{Bu}$ amaç doğrultusunda yapılan literatür taraması sonucu elde edilen kriterler anket formuna dönüştürülmüş ve ülke genelinden 118 inşaat mühendisinden veri toplanmıştır. Toplanan veriler SPSS 18 paket programı ile istatistiksel olarak değerlendirilmiştir.

\section{Materyal ve metot}

\subsection{Materyal}


İnşaat sektöründe özel yatırımlar büyük yer tutmakla birlikte, son y1llarda özel sektör yatırımlarının büyüme hızının kamu yatırımlarına göre daha fazla olması inşaat işlerinde özel sektör çalışanlarına dikkat çekmektedir [19]. İnşaat işlerinin genel yapısında olan belirsizliklerle, özel yatırımlarda daha fazla karşılaşılmakta; bu durum ise çalışanlar üzerinde pek çok olumsuz duruma yol açmaktadır. Bu nedenle, çalışmanın örneklemini Türkiye genelinde özel sektörde çalışan inşaat mühendisleri oluşturmaktadır. Yap1 üretim sürecinde, proje hedeflerinin gerçekleştirilmesinde inşaat mühendisleri önemli rol oynamaktadırlar. Bu nedenle, Türk inşaat sektöründe özel sektörde inşaat mühendisi olarak faaliyet gösteren 118 katılımcıdan anket yöntemiyle veri toplanmıştır.

\subsection{Metot}

İnşaat mühendislerini demotive eden faktörlerin belirlenmesi için veri toplama araci olarak araştırmaya yönelik olarak hazırlanan anket formu kullanılmıştır. Anket soruları, yapılan literatür çalışmaları sonucunda incelenen motivasyon araçları [20-27]. göz önüne alınarak hazırlanmıştır. Anket iki bölümden oluşmaktadır. Anketin birinci bölümünde demotivasyon ile ilgili belirlenmiş olan altmış dokuz adet kriterin, katılımcıları ne oranda etkilediği ile ilgili görüşlerini belirtmeleri istenmiştir. Araştırmada, katılımcıları demotive eden kriterleri belirlemek amacıyla hazırlanan sorularda 5' li Likert ölçeği kullanılmıştır. Anketin ikinci bölümde ise ankete katılanların demografik özelliklerini belirlemek amacıyla sorular sorulmuştur.

Anketler katılımcılara e-posta aracılığı ile ulaştırılmış ve veriler e-posta yoluyla toplanmıştır. E-posta yoluyla toplanan veriler için anket online hale getirilmiştir. Veri toplanması için hazırlanan anket formu Ağustos-Ekim 2015 tarihleri arasında internet yoluyla ülke genelindeki katılımcılara online olarak ulaştırılmıştır. Bununla birlikte anket formu meslek odalarına ve birliklere bağlı üyelere de internet ortamında ulaştırılmış ve adı geçen birliklerden anketleri üyelerine ulaştırmaları konusunda destek alınmıştır.

Araştırmanın örneklem büyüklüğünü, ana kitleden rastgele örneklem seçimi yöntemi ile belirlenen Türk inşaat sektöründe, özel sektörde aktif şekilde faaliyet gösteren 118 inşaat mühendisi oluşturmaktadır. Katılımcılardan elde edilen verilerin analizleri "SPSS 18 for Windows" ve "Microsoft Office Excel 2010" yazılım programları aracılığı ile yapılmıştır.

Verilerin normal dağılım gösterip göstermediği Kolmogorov-Smirnov testi ile test edilmiştir. Kolmogorov-Smirnov testi rasgele elde edilmiş örnek bir veri setinin belirli bir dağılıma (uniform, normal) uyup uymadığını test etmek amacıyla kullanılır [28]. Analiz sonucunda bütün değişsenlerin normal dağılım gösterdikleri belirlemiştir. Bu nedenle hipotez testlerinde ikili grupların karşılaştırmasında (cinsiyet, medeni durum ve görev pozisyonu değişkenleri için) bağımsız örnek t-testi; ikiden fazla grupların karşılaştırılmasında (yaş değişkeni için) tek yönlü varyans analizi (ANOVA) kullanılmış ve sonuçlar $\mathrm{p}<0.05$ önem düzeyinde test edilmiştir. Bağımsız iki örnek $\mathrm{t}-$ testi, bağımsız iki toplumun parametrelerine dayalı olarak kurulan hipotezlerin, bağımsız iki örnekten elde edilen nicel ve nitel verilerin istatistikleri kullanarak test edilmesinde yararlanılır [29]. Tek yönlü varyans analizi iki ya da daha fazla ortalama arasından fark olup olmadığı ile ilgili hipotezi test etmek için kullanılır. Varyans analizinde temel hedef ortalamalar arasında fark olup olmadığını anlamaktır [28]. 


\section{Bulgular}

$\mathrm{Bu}$ bölümde öncelikle çalışma için geliştirilen anketin güvenilirliği test edilmiş ve örnekleme ait demografik özellikler belirlenmiştir. Daha sonra demotivasyon kriterleri ile demografik özellikler arasındaki ilişkilerin sorgulandığı hipotez testi sonuçlarına yer verilmiş ve son olarak belirlenen demotivasyon kriterlerine faktör analizi uygulanarak özel sektörde çalışan inşaat mühendislerini demotive eden faktörler belirlenmiştir.

\subsection{Anketin güvenilirlik analizi}

Ankette yer alan demografik sorular dişında ki algıya dayalı atmış dokuz demotivasyon kriterine, içsel tutarlılığı ölçmek amacıyla güvenilirlik analizi uygulanmıştır. Analiz sonucunda Cronbach's Alfa değerinin $\alpha=0,979$ olarak oluştuğu görülmektedir. Cronbach Alpha değerinin 0,8'in üzerinde olması, anketin yüksek derecede güvenilir olduğunu göstermektedir [28].

\subsection{Katılımcıların demografik özellikleri}

Katılımcıların cinsiyet, yaş, medeni durum, eğitim düzeyi ve görev pozisyonu ile ilgili sorulara verdikleri cevapların dağılımı Tablo 1'de özetlenmiştir.

Tablo 1 incelendiğinde katılımcıların büyük çoğunluğunun (\%92.4) erkek olduğu görülmektedir. $\mathrm{Bu}$ durum, inşaat sektöründe erkek cinsiyetin çoğunlukta olmasından kaynaklandığı düşünülmektedir.

Katılımcılar yaş değiş̧kenine göre incelendiğinde büyük çoğunluğun (\%60.2) 23-30 yaş arası genç mühendisler olduğu görülmekle birlikte, her yaş grubundan katılım sağlandığı görülmektedir.

Tablo 1. Katılımcıların demografik özellikleri

\begin{tabular}{|c|c|c|}
\hline Demografik Özellikler & $\begin{array}{l}\text { Frekans } \\
\text { (f) }\end{array}$ & $\begin{array}{c}\begin{array}{l}\text { Yüzde } \\
(\%)\end{array} \\
\end{array}$ \\
\hline \multicolumn{3}{|l|}{ Cinsiyet } \\
\hline Kadın & 9 & 7.6 \\
\hline Erkek & 109 & 92.4 \\
\hline \multicolumn{3}{|l|}{ Yaş } \\
\hline $23-30$ & 71 & 60.2 \\
\hline $31-38$ & 34 & 28.8 \\
\hline $39-46$ & 4 & 3.4 \\
\hline $47-54$ & 4 & 3.4 \\
\hline 55 ve üzeri & 5 & 4.2 \\
\hline \multicolumn{3}{|l|}{ Eğitim Düzeyi } \\
\hline Lisans & 101 & 85.6 \\
\hline Yüksek lisans & 17 & 14.4 \\
\hline Doktora & 0 & 0.0 \\
\hline \multicolumn{3}{|l|}{ Medeni Durum } \\
\hline Bekar & 67 & 56.8 \\
\hline$\overline{\text { Evli }}$ & 51 & 43.2 \\
\hline \multicolumn{3}{|l|}{ Görev Pozisyonu } \\
\hline Yönetici & 53 & 44.9 \\
\hline Çalışan & 65 & 55.1 \\
\hline
\end{tabular}


Katılımcılar eğitim durumlarına göre incelendiğinde, büyük çoğunluğunun (\%85.6) lisans derecesine sahip olduğu belirlenmiştir. Çalışmaya katılan mühendislerin büyük çoğunluğu çalışan pozisyonunda çalışmakla birlikte (\%55.1) yönetici pozisyonunda olan mühendisler de önemli bir çoğunluğa sahiptir (\%44.9).

\subsection{Demotivasyon kriterleri}

Yapılan literatür çalışması sonucu elde edilen ve 5'li Likert ölçeği kullanılarak anket formunda yer alan altmış dokuz adet demotivasyon kriterleri Tablo 2'de yer almaktadır. Bu tabloda her bir demotivasyon kriteri DK1, DK2,...., DK69 olarak numaralandırılmış ve yanındaki sütunda da kriterin içeriği tanımlanmıştır. Tablo 3, Tablo 4 ve Tablo 5 'de tekrar olmaması amacıyla adı geçen tablolarda sadece kriterlerin numaralarına yer verilmiştir.

\section{Tablo 2. Demotivasyon kriterleri}

\begin{tabular}{|c|c|}
\hline Kriter No & Kriter Adı \\
\hline DK1 & Çalışma ekibinin kendi içindeki zayıf iletişimi \\
\hline DK2 & Çalışma ekibinin kendi içindeki zayıf koordinasyonu \\
\hline DK3 & Çalışma ekibi üyelerinin birbirinden farklı özellikler taşıması \\
\hline DK4 & Çalışma arkadaşları arasındaki rekabet \\
\hline DK5 & Çalıssma ekibi içindeki yeteneksiz kișiler \\
\hline DK6 & Çalıșma ekibi üyeleri arasında sorumluluk duygusunun eksik olması \\
\hline DK7 & Çalışma ekibi üyelerinin kendi içindeki iş birliği yetersizliği \\
\hline DK8 & $\begin{array}{l}\text { Çalışma ekibi üyelerinin kendi içindeki dürüstlüğün az olması veya hiç olmaması, } \\
\text { güvensizlik ortamı }\end{array}$ \\
\hline DK9 & Çalıșma arkadaşları arasındaki saygı eksikliği \\
\hline DK10 & Çalışma arkadaşları arasında canlılığın ve dinamizmin eksik olması \\
\hline DK11 & Farklı cinsiyetteki çalışanların izole olması, soyutlanması \\
\hline DK12 & Çalışma ekibi üyeleri arasında yardımlaşma olmaması \\
\hline DK13 & $\begin{array}{l}\text { İş dışında sosyal aktivite (yemek, piknik, spor, konser vb.) imkânlarının yetersiz olması } \\
\text { veya hiç olmaması }\end{array}$ \\
\hline DK14 & Ekip üyelerinin işlerini severek yapmamaları \\
\hline DK15 & $\begin{array}{l}\text { Çalışlan kurumun/firmanın sağladığı } \\
\text { olanaklarının yeterli düzeyde olmaması }\end{array}$ \\
\hline DK16 & Alınan maaşın yeterli olmaması \\
\hline DK17 & Aynı görev pozisyonunda çalışanların maaşlarının eşit ve adaletli olmaması \\
\hline DK18 & İș yerinde maaș dıșı yapılan prim gibi parasal ödüllerin olmaması \\
\hline DK 19 & İș yerinde maaș dıș yapılan prim gibi parasal ödüllerin çalışanlara adil dağıtılmaması \\
\hline DK20 & Maaşın ve primlerin zamaninda ödenmemesi \\
\hline DK21 & İș yerinde yükselme/terfi şansının olmaması \\
\hline DK 22 & Yapılan işin takdir edilmemesi \\
\hline DK23 & İşlerin çalışanlar arasında adil olarak dağıtılmaması \\
\hline DK24 & İş yükünün aşırı olması \\
\hline DK 25 & Çalışma saatlerinin yoğun olması, uygun olmaması \\
\hline DK26 & Yapılan iși etkileyecek konularda kararlara katılma hakkına sahip olunmaması \\
\hline DK27 & Yapılan ișin ilginç ve ilgi çekici olmaması \\
\hline DK 28 & Yapılan işin bilgi ve yeteneğine uygun olmaması \\
\hline DK29 & $\begin{array}{l}\text { Çalışma ortamındaki fiziksel koşulların(aydınlatma, ssıtma, havalandırma, temizlik, ses) } \\
\text { yetersiz olması }\end{array}$ \\
\hline DK30 & $\begin{array}{l}\text { Kullanılan araç ve gereçlerin(teknik ekipman, bilgisayar vb.) sayıca ve nitelik olarak } \\
\text { yetersiz olması }\end{array}$ \\
\hline DK31 & Firmanın ücretsiz öğle yemeği, çay-kahve gibi imkânlar sunmaması \\
\hline DK32 & İș yerindeki tatil ve izinlerin yetersizliği, hak edilmiş olan izinlerin verilmemesi \\
\hline DK33 & Hizmet içi eğitim olanaklarının olmaması \\
\hline DK34 & Mesleki gelişimi sağlayan, kariyer imkânının olmaması \\
\hline DK35 & İş yerinde gerekli ve yeterli iş güvenliği önlemlerinin olmaması \\
\hline
\end{tabular}


Tablo 2. devamı

\begin{tabular}{|c|c|}
\hline Kriter No & Kriter Adı \\
\hline DK36 & $\begin{array}{l}\text { Çalışanlar arasında görev dağılımının ve işe yönelik görev tanımlamalarının net olarak } \\
\text { yapılmaması veya hiç yapılmaması }\end{array}$ \\
\hline DK37 & Verilen işi yapabilmek için yeterli yetkiye sahip olmamak \\
\hline DK38 & Ortaya konan yeni fikirlerin yöneticiler/yetkililer tarafindan dikkate alınmamas1 \\
\hline DK39 & İș ortamında bağımsız düșünme ve hareket etme imkânının olmaması \\
\hline DK40 & $\begin{array}{l}\text { Yöneticinin çalşsanlarına işteki performansları hakkında yeterli ve düzenli olarak bilgi } \\
\text { vermemesi }\end{array}$ \\
\hline DK41 & Yetki ve sorumlulukların dengeli olmaması \\
\hline DK42 & Organizasyon politikalarının performans ve başarıyı engellemesi \\
\hline DK43 & Çalışanlara yaratıcılıklarını kullanma hakkının verilmemesi \\
\hline DK44 & $\begin{array}{l}\text { Çalışanların kendini kuruma/firmaya ait hissetmemesi, firmanın ilke ve amaçlarını } \\
\text { benimsememesi }\end{array}$ \\
\hline DK45 & Organizasyon içindeki yetersiz planlama, kontrol ve denetim \\
\hline DK46 & İşle ilgili konularda çalışanların kendi inisiyatiflerini kullanamaması \\
\hline DK47 & Yönetici ve çalışanlar arasındaki zayıf iletişim \\
\hline DK48 & Yönetici ve çalışanlar arasındaki zayıf koordinasyon \\
\hline DK49 & $\begin{array}{l}\text { Yöneticilerin diktatörlük, zorbalık, korkutma, yıldırma gibi olumsuz tutum ve } \\
\text { davranışlar1 }\end{array}$ \\
\hline DK50 & Yönetici desteğinin yetersizliği \\
\hline DK51 & Çalışma ortamında negatif eleştirilere odaklanılması \\
\hline DK 52 & Müdür tarafindan proje önceliklerinin sürekli değişmesi \\
\hline DK53 & Tasarımı tamamlanmış projelerde müşterilerin radikal ve köklü değişiklikler istemesi \\
\hline DK54 & Tasarım kararları alınırken kalite yerine maliyetin düșünülmesi ve etkili olması \\
\hline DK 55 & Müşterilerin gerçekçi olmayan proje istekleri \\
\hline DK56 & $\begin{array}{l}\text { Müssterilerin ve öteki proje paydaşlarının(inşaat mühendisi, elektrik mühendisi, makine } \\
\text { mühendisi, malzeme tedarikçisi vb.) iş birlikçi olmayan tutum ve davranışları }\end{array}$ \\
\hline DK57 & $\begin{array}{l}\text { Müsterilerin kendilerine özgü istek ve ihtiyaçlarını açıkça belirtmemelerine rağmen bu } \\
\text { isteklerinin karşılanmasını beklemeleri }\end{array}$ \\
\hline DK 58 & Organizasyonun amaçları ve yöneticilerin davranışları arasındaki sinerji eksikliği \\
\hline DK59 & $\begin{array}{l}\text { Yasal mevzuatların(yasa ve yönetmeliklerin) mimari tasarımlara kısitlayıcı ve olumsuz } \\
\text { etkisi }\end{array}$ \\
\hline DK60 & Yöneticinin çalışanlara ve yaptığı işlere saygı duymaması \\
\hline DK 61 & Yapılan işlerdeki başarısızlıkların fazla olması \\
\hline DK62 & $\begin{array}{l}\text { Firmaya gelen işlerin yıl içinde sürekli ve dengeli olmaması (bazı aylarda iş yükünün } \\
\text { çok fazla olması, bazı aylarda hiç olmaması) }\end{array}$ \\
\hline DK63 & Firmadaki kâos ortamı \\
\hline DK64 & Müşterilerin memnuniyetsizlikleri \\
\hline DK65 & Uzak mesafe iş seyahatlerine katılma zorunluluğu \\
\hline DK66 & İș disiplininin olmaması \\
\hline DK67 & Kültürel farklılıklar/çok farklı kültürden insanların bir arada çalışması \\
\hline DK68 & Ev ile iş yeri arasındaki mesafenin uzak olması-ulaşım sorunu yaşanması \\
\hline DK69 & İş yerinin şehir merkezinden uzak olması \\
\hline
\end{tabular}

\subsection{Demotivasyon kriterleri ile çeşitli değişkenler arası hipotez testleri}

Hipotez testleri kapsamında, belirlenmiş olan 69 demotivasyon kriteri ile çeşitli değişkenler arasında ilişki olup olmadığı araştırılmıştır. Bu çerçevede iki farklı hipotez testi kullanılmıştır. Daha önce "Materyal ve Metot" bölümünde de belirtildiği gibi elde edilen veriler normal dağılıma sahip olduğu için parametrik hipotez testlerinden "Bağımsız iki örnek t-testi (Independent-sample t-test) ve Tek Yönlü ANOVA (OneWay ANOVA) kullanılmıştır. Kullanılan her iki tür hipotez testinde de 69 kriter için ayrı ayrı analizler yapılmıştır. Adı geçen demotivasyon kriterleri ile inşaat mühendislerinin cinsiyet, medeni durumu, görev pozisyonları ve yaş değişkenleri arasında anlamlı ilişki olup olmadığı araştırılmıştır. Bununla birlikte yapılan hipotez 
testlerinde Significance değerlerinin bir bütün olarak algılanabilmesi için inşaat mühendislerini demotive eden kriterlere uygulanan hipotez testleri ayn tabloda verilmiştir (Tablo 3).

Tablo 3'de belirtilen Significance (Sig.) değerlerinin 0,05 değerinden küçük olması H1 hipotezinin kabul edilmesi gerektiğini, diğer bir ifade ile ilgili demotivasyon kriteri ile incelenen değişken (cinsiyet, medeni durum, vs) arasında anlamlı bir ilişki olduğunu ifade etmektedir. Significance değeri 0,05 'e eşit ve küçük olan değişkenler Tablo 3 'de belirtilmiştir.

Tablo 3. Cinsiyet, medeni durum, görev pozisyonu ve yaş ile ilgili hipotez testleri

\begin{tabular}{|c|c|c|c|c|}
\hline Demotivasyon Kriterleri & $\begin{array}{l}\text { Cinsiyet } \\
\text { (Sig.) }\end{array}$ & $\begin{array}{l}\text { Medeni durum } \\
\text { (Sig.) }\end{array}$ & $\begin{array}{l}\text { Görev pozisyonu } \\
\text { (Sig.) }\end{array}$ & $\begin{array}{l}\text { Yaş } \\
\text { (Sig.) }\end{array}$ \\
\hline DK1 & 0.002* & 0.725 & 0.170 & 0.358 \\
\hline DK2 & 0.001* & 0.849 & 0.132 & 0.483 \\
\hline DK3 & 0.157 & 0.341 & 0.089 & 0.875 \\
\hline DK4 & 0.308 & $0.025 *$ & 0.104 & 0.065 \\
\hline DK5 & 0.154 & 0.623 & 0.043* & 0.350 \\
\hline DK6 & 0.019* & 0.942 & 0.057 & 0.411 \\
\hline DK7 & 0.348 & 0.302 & 0.076 & 0.380 \\
\hline DK8 & 0.024* & 0.284 & 0.021* & 0.248 \\
\hline DK9 & 0.004* & 0.332 & 0.005* & 0.85 \\
\hline DK10 & 0.471 & 0.728 & 0.154 & 0.972 \\
\hline DK11 & 0.002* & 0.885 & 0.360 & 0.639 \\
\hline DK12 & 0.022* & 0.965 & 0.208 & 0.581 \\
\hline DK13 & 0.843 & 0.130 & 0.103 & 0.328 \\
\hline DK14 & 0.332 & 0.855 & 0.044* & 0.332 \\
\hline DK15 & 0.990 & 0.803 & 0.003* & 0.768 \\
\hline DK16 & 0.791 & 0.628 & 0.011* & 0.509 \\
\hline DK17 & 0.053 & 0.914 & 0.001* & 0.416 \\
\hline DK18 & 0.164 & 0.465 & 0.145 & 0.588 \\
\hline DK 19 & 0.274 & 0.917 & 0.013* & 0.848 \\
\hline DK20 & 0.057 & 0.155 & 0.020* & 0.356 \\
\hline DK21 & 0.096 & 0.962 & 0.002* & 0.633 \\
\hline DK 22 & 0.032* & 0.542 & 0.024* & 0.398 \\
\hline DK23 & 0.003* & 0.098 & 0.000* & 0.456 \\
\hline DK24 & 0.065 & 0.977 & 0.000* & 0.483 \\
\hline DK 25 & 0.367 & 0.074 & 0.000* & 0.256 \\
\hline DK26 & 0.100 & 0.242 & 0.000* & 0.530 \\
\hline DK27 & 0.376 & 0.332 & 0.055 & 0.303 \\
\hline DK 28 & 0.018* & 0.358 & 0.054 & 0.059 \\
\hline DK29 & 0.245 & 0.508 & 0.043* & 0.746 \\
\hline DK30 & 0.160 & 0.708 & 0.122 & 0.987 \\
\hline DK31 & 0.038* & 0.242 & 0.020* & 0.741 \\
\hline DK32 & 0.221 & 0.768 & 0.002* & 0.193 \\
\hline DK33 & 0.189 & $0.025^{*}$ & 0.000* & 0.334 \\
\hline DK34 & 0.099 & $0.029 *$ & 0.001* & 0.173 \\
\hline DK35 & 0.092 & 0.081 & $\mathbf{0 . 0 3 5}^{*}$ & 0.243 \\
\hline DK36 & 0.512 & 0.433 & $\mathbf{0 . 0 0 3}^{*}$ & 0.801 \\
\hline DK37 & 0.298 & 0.215 & 0.043* & 0.590 \\
\hline DK38 & $\mathbf{0 . 0 8 7}$ & 0.245 & 0.000* & 0.404 \\
\hline DK39 & 0.029* & 0.174 & 0.000* & 0.329 \\
\hline DK40 & 0.230 & 0.082 & 0.020* & 0.116 \\
\hline DK41 & 0.827 & 0.506 & 0.011* & 0.164 \\
\hline DK42 & 0.761 & 0.807 & 0.001* & 0.852 \\
\hline DK43 & 0.131 & 0.201 & $0.017 *$ & 0.319 \\
\hline
\end{tabular}


Tablo 3. devamı

\begin{tabular}{|c|c|c|c|c|}
\hline Demotivasyon Kriterleri & $\begin{array}{l}\text { Cinsiyet } \\
\text { (Sig.) }\end{array}$ & $\begin{array}{l}\text { Medeni durum } \\
\text { (Sig.) }\end{array}$ & $\begin{array}{l}\text { Görev pozisyonu } \\
\text { (Sig.) }\end{array}$ & $\begin{array}{l}\text { Yaş } \\
\text { (Sig.) }\end{array}$ \\
\hline DK44 & 0.313 & 0.817 & 0.218 & 0.753 \\
\hline DK45 & 0.044* & 0.599 & 0.010* & 0.640 \\
\hline DK46 & 0.583 & 0.361 & 0.002* & 0.600 \\
\hline DK47 & 0.009* & 0.999 & 0.002* & 0.678 \\
\hline DK48 & 0.010* & 0.945 & 0.000* & 0.509 \\
\hline DK49 & 0.087 & 0.342 & 0.000* & 0.129 \\
\hline DK50 & 0.010* & 0.269 & 0.000* & 0.169 \\
\hline DK51 & 0.033* & 0.905 & 0.000* & 0.271 \\
\hline DK52 & 0.070 & 0.425 & 0.001* & 0.493 \\
\hline DK53 & 0.024* & 0.628 & 0.051 & 0.321 \\
\hline DK54 & 0.004* & 0.188 & 0.001* & 0.405 \\
\hline DK55 & $0.015 *$ & 0.788 & 0.010* & 0.986 \\
\hline DK56 & 0.007* & 0.683 & 0.003* & 0.733 \\
\hline DK57 & 0.125 & 0.343 & 0.017* & 0.754 \\
\hline DK58 & 0.166 & 0.693 & 0.276 & 0.948 \\
\hline DK59 & 0.241 & 0.228 & 0.175 & 0.877 \\
\hline DK60 & 0.020* & 0.741 & 0.009* & 0.630 \\
\hline DK61 & 0.124 & $0.007 *$ & 0.305 & 0.060 \\
\hline DK62 & 0.589 & $0.009^{*}$ & 0.013* & 0.526 \\
\hline DK63 & 0.092 & 0.775 & 0.124 & 0.504 \\
\hline DK64 & 0.297 & 0.630 & 0.064 & 0.376 \\
\hline DK65 & 0.130 & 0.197 & 0.166 & 0.581 \\
\hline DK66 & $0.046 *$ & 0.217 & 0.029* & 0.318 \\
\hline DK67 & 0.030* & $0.020 *$ & 0.039* & $0.050^{*}$ \\
\hline DK68 & 0.009* & 0.062 & 0.011* & 0.377 \\
\hline DK69 & 0.246 & $0.031 *$ & 0.146 & 0.580 \\
\hline
\end{tabular}

${ }^{*} \mathrm{p}<0.05$

Tablo 3'de yapılan hipotez testleri incelendiğinde, literatür çalışması sonucunda belirlenmiş olan atmış dokuz demotivasyon kriterinden DK1 (Çalışma ekibinin kendi içindeki zayıf iletişimi); DK2 (Çalışma ekibinin kendi içindeki zayıf koordinasyonu); DK6 (Çalışma ekibi üyeleri arasında sorumluluk duygusunun eksik olması); DK8 (Çalışma ekibi üyelerinin kendi içindeki dürüstlüğün az olması veya hiç olmaması, güvensizlik ortamı); DK9 (Çalışma arkadaşları arasındaki saygı eksikliği); DK11 (Farklı cinsiyetteki çalışanların izole olması, soyutlanması); DK12 (Çalışma ekibi üyeleri arasında yardımlaşma olmaması); DK22 (Yapılan işin takdir edilmemesi); DK23 (İşlerin çalışanlar arasında adil olarak dağıtılmaması); DK28 (Yapılan işin bilgi ve yeteneğine uygun olmaması); DK31 (Firmanın ücretsiz öğle yemeği, çay-kahve gibi imkânlar sunmaması); DK39 (İş ortamında bağımsız düşünme ve hareket etme imkânının olmaması); DK45 (Organizasyon içindeki yetersiz planlama, kontrol ve denetim); DK47 (Yönetici ve çalışanlar arasındaki zayıf iletişim); DK48 (Yönetici ve çalışanlar arasındaki zayıf koordinasyon); DK50 (Yönetici desteğinin yetersizliği); DK51 (Çalışma ortamında negatif eleştirilere odaklanılması); DK53 (Tasarımı tamamlanmış projelerde müşterilerin radikal ve köklü değişiklikler istemesi); DK54 (Tasarım kararları alınırken kalite yerine maliyetin düşünülmesi ve etkili olması); DK55 (Müşterilerin gerçekçi olmayan proje istekleri); DK56 (Müşterilerin ve öteki proje paydaşlarının iş birlikçi olmayan tutum ve davranışları); DK60 (Yöneticinin çalışanlara ve yaptığı işlere saygı duymaması); DK66 (İş disiplininin olmaması); DK67 (Kültürel farklılıklar/çok farklı kültürden insanların bir arada çalışması); DK68 (Ev ile iş yeri arasındaki mesafenin uzak olması-ulaşım sorunu yaşanması) kriterleri ile özel sektörde 
çalışan inşaat mühendislerinin cinsiyetleri arasında anlamlı ilişki vardır. Kadın ve erkek inşaat mühendislerinin ortalama farkları incelendiğinde ise kadın inşaat mühendislerinin ortalamalarının erkek mühendislerinden fazla olduğu görülmüştür. Diğer bir ifade ile aralarında ilişki belirlenen her bir demotivasyon kriterinin kadınları erkeklerden daha çok etkilediği belirlenmiştir.

Medeni durum ile demotivasyon kriterleri arasındaki ilişki incelendiğinde ise DK4 (Çalışma arkadaşları arasındaki rekabet); DK33 (Hizmet içi eğitim olanaklarının olmamas1); DK34 (Mesleki gelişimi sağlayan, kariyer imkânının olmaması); DK61 (Yapılan işlerdeki başarısızlıkların fazla olması); DK62 (Firmaya gelen işlerin yıl içinde sürekli ve dengeli olmaması);DK67 (Kültürel farklılıklar/çok farklı kültürden insanların bir arada çalışması); DK69 (İş yerinin şehir merkezinden uzak olması) kriterleri arasında anlamlı ilişki olduğu görülmektedir (Tablo 3). Gruplar arasındaki ortalama farkları incelendiğinde ise DK4, DK33, DK34, DK67 ve DK69 bekar mühendisleri evli olanlara göre daha çok etkilemekte iken, DK61 ve DK62 ise evli olan inşaat mühendislerini bekar olanlara göre daha çok etkilemektedir.

Görev pozisyonuna ile demotivasyon kriterlerinin arasındaki ilişki analiz edildiğinde atmış dokuz demotivasyon kriterinin kırk yedisiyle görev pozisyonu arasında anlamlı ilişki olduğu belirlenmiştir (Tablo 3). Gruplar arasındaki ortalama farkları incelendiğinde ise çalışan pozisyonundaki inşaat mühendislerinin yönetici pozisyonundaki mühendislere göre Tablo 3'de belirlenen kırk yedi adet demotivasyon kriterinden daha çok etkilendiği belirlenmiştir.

Son olarak yapılan hipotez testinde ise özel sektörde çalışan inşaat mühendislerinin yaşı ile demotivasyon kriterleri arasındaki ilişki belirlenmeye çalışılmıştır, ancak hiçbir demotivasyon kriteri ile mühendislerin yaşı arasında anlamlı bir ilişki bulunamamıştır.

\subsection{Demotivasyon kriterlerinin önem stralaması}

Demotivasyon kriterlerinin özel sektörde çalışan inşaat mühendislerini ne düzeyde etkilediğini ve/veya etkilemediğini belirlemek amacıyla katılımcıların verdikleri cevaplara göre kriterlerin önem sıralaması yapılmıştır. Bu kapsamda katılımcıları en fazla ve en az düzeyde hangi kriterlerin demotive ettiğinin belirlenmesi amaçlanmıştır. $\mathrm{Bu}$ amaç doğrultusunda Chan ve Kumaraswamy [30], çalışmalarında kullandıkları formül (Denklem 1) kullanılarak özel sektörde çalışan inşaat mühendisleri için demotivasyon kriterlerinin önem sıralaması yapılmıştır (Tablo 4).

Demotivasyon kriteri önem sıralaması (DKÖS):

DKÖS $={ }_{i=1}^{N}(\mathrm{si}) / \mathrm{NS}$

Denklem 1'deki N toplam katılımcı sayısını, S ilgili demotivasyon kriteri için verilebilecek en yüksek puanı (5'li Likert ölçeği kullanıldığından bu çalışma için 5) ifade etmektedir.

Tablo 4 incelendiğinde özel sektörde çalışan inşaat mühendislerini en çok demotive eden beş kriter DK17-Aynı görev pozisyonunda çalışanların maaşlarının eşit ve adaletli olmaması, DK16- Alınan maaşın yeterli olmaması, DK49- Yöneticilerin diktatörlük, zorbalık, korkutma, yıldırma gibi olumsuz tutum ve davranışları, DK6- Çalışma ekibi 
üyeleri arasında sorumluluk duygusunun eksik olması ve DK8-Çalışma ekibi üyelerinin kendi içindeki dürüstlüğün az olması veya hiç olmaması, güvensizlik ortamıdır.

Tablo 4. Demotivasyon kriterlerinin önem siralaması

\begin{tabular}{|c|c|c|c|c|c|}
\hline Demotivasyon Kriterleri & DSI & Siralama & Demotivasyon Kriterleri & DSI & Siralama \\
\hline DK1 & 19.110 & 12 & DK15 & 18.305 & 27 \\
\hline DK2 & 19.703 & 6 & DK16 & 20.508 & 2 \\
\hline DK3 & 11.949 & 68 & DK17 & 20.593 & 1 \\
\hline DK4 & 13.813 & 65 & DK18 & 17.542 & 34 \\
\hline DK5 & 19.322 & 9 & DK19 & 19.279 & 10 \\
\hline DK6 & 19.788 & 4 & DK20 & 19.661 & 7 \\
\hline DK7 & 18.898 & 15 & DK21 & 18.855 & 16 \\
\hline DK8 & 19.745 & 5 & DK22 & 19.533 & 8 \\
\hline DK9 & 18.347 & 26 & DK23 & 18.728 & 18 \\
\hline DK10 & 16.694 & 43 & DK24 & 18.559 & 24 \\
\hline DK11 & 13.135 & 66 & DK25 & 19.111 & 11 \\
\hline DK12 & 16.695 & 42 & DK26 & 17.500 & 35 \\
\hline DK13 & 14.872 & 62 & DK27 & 14.873 & 61 \\
\hline DK14 & 17.372 & 37 & DK28 & 15.720 & 56 \\
\hline DK29 & 17.033 & 39 & DK50 & 18.686 & 20 \\
\hline DK30 & 17.754 & 31 & DK51 & 18.177 & 28 \\
\hline DK31 & 15.508 & 57 & DK52 & 17.373 & 36 \\
\hline DK32 & 19.025 & 13 & DK53 & 17.034 & 38 \\
\hline DK33 & 15.423 & 58 & DK54 & 15.975 & 51 \\
\hline DK34 & 16.610 & 46 & DK55 & 15.805 & 55 \\
\hline DK35 & 16.186 & 49 & DK56 & 17.669 & 33 \\
\hline DK36 & 18.348 & 25 & DK57 & 16.187 & 48 \\
\hline DK37 & 17.711 & 32 & DK58 & 15.974 & 52 \\
\hline DK38 & 17.881 & 30 & DK59 & 14.322 & 64 \\
\hline DK39 & 16.567 & 47 & DK60 & 18.771 & 17 \\
\hline DK40 & 15.847 & 54 & DK61 & 16.864 & 40 \\
\hline DK41 & 16.822 & 41 & DK62 & 15.211 & 60 \\
\hline DK42 & 16.144 & 50 & DK63 & 18.687 & 19 \\
\hline DK43 & 15.889 & 53 & DK64 & 16.653 & 44 \\
\hline DK44 & 17.966 & 29 & DK65 & 13.093 & 67 \\
\hline DK45 & 18.601 & 23 & DK66 & 18.983 & 14 \\
\hline DK46 & 16.652 & 45 & DK67 & 11.567 & 69 \\
\hline DK47 & 18.602 & 22 & DK68 & 15.254 & 59 \\
\hline DK48 & 18.644 & 21 & DK69 & 14.788 & 63 \\
\hline DK49 & 19.915 & 3 & & & \\
\hline
\end{tabular}

En az demotive eden beş kriter ise DK4- Çalışma arkadaşları arasındaki rekabet, DK11Farklı cinsiyetteki çalışanların izole olması, soyutlanması, DK65- Uzak mesafe iş seyahatlerine katılma zorunluluğu, DK3-Çalışma ekibi üyelerinin birbirinden farklı özellikler taşıması, DK67- Kültürel farklılıklar/çok farklı kültürden insanların bir arada çalışmasıdır.

\subsection{Demotivasyon faktörlerinin belirlenmesi-açımlayıcı faktör analizi}

Literatür çalışması sonucunda elde edilen atmış dokuz demotivasyon kriterine özel sektörde çalışan inşaat mühendislerinin anket sorularına verdikleri cevaplara göre açımlayıcı faktör analizi uygulanmış ve bu değişkenlere ait faktör yapıları ortaya çıkarılmıştır. Analiz sonuçları Tablo 5'de görüldüğü gibidir. 
Tablo 5. Faktör analizi

\begin{tabular}{|c|c|c|c|c|c|c|c|}
\hline Faktörler & Öz değer & $\begin{array}{l}\text { Varyansın } \\
\text { yüzdesi (\%) }\end{array}$ & $\begin{array}{l}\text { Faktör } \\
\text { Yükü }\end{array}$ & Faktörler & $\begin{array}{l}\text { Öz } \\
\text { değer }\end{array}$ & $\begin{array}{l}\text { Varyansın } \\
\text { yüzdesi (\%) }\end{array}$ & $\begin{array}{l}\text { Faktör } \\
\text { Yükü }\end{array}$ \\
\hline Faktör 1 & 29.602 & 42.901 & & Faktör 3 & 2.959 & 4.288 & \\
\hline DK47 & & & 0.752 & DK39 & & & 0.718 \\
\hline DK48 & & & 0.741 & DK26 & & & 0.717 \\
\hline DK50 & & & 0.698 & DK38 & & & 0.672 \\
\hline DK49 & & & 0.650 & DK41 & & & 0.633 \\
\hline DK46 & & & 0.606 & DK42 & & & 0.609 \\
\hline DK63 & & & 0.602 & DK43 & & & 0.543 \\
\hline DK51 & & & 0.594 & DK40 & & & 0.525 \\
\hline DK45 & & & 0.562 & DK36 & & & 0.494 \\
\hline DK37 & & & 0.527 & DK34 & & & 0.465 \\
\hline DK66 & & & 0.464 & DK27 & & & 0.459 \\
\hline DK9 & & & 0.446 & Faktör 4 & 2.458 & 3.563 & \\
\hline Faktör 2 & 3.127 & 4.532 & & DK16 & & & 0.747 \\
\hline DK55 & & & 0.790 & DK19 & & & 0.657 \\
\hline DK54 & & & 0.788 & DK15 & & & 0.640 \\
\hline DK57 & & & 0.762 & DK18 & & & 0.635 \\
\hline DK53 & & & 0.751 & DK17 & & & 0.632 \\
\hline DK56 & & & 0.710 & DK24 & & & 0.575 \\
\hline DK64 & & & 0.622 & DK25 & & & 0.534 \\
\hline DK52 & & & 0.556 & DK21 & & & 0.527 \\
\hline DK58 & & & 0.493 & DK20 & & & 0.506 \\
\hline DK60 & & & 0.461 & DK22 & & & 0.449 \\
\hline \multicolumn{4}{|l|}{ DTNO } & DK23 & & & 0.421 \\
\hline Faktör 5 & 2.191 & 3.176 & & Faktör 8 & 1.615 & 2.341 & \\
\hline DK2 & & & 0.742 & DK11 & & & 0.686 \\
\hline DK7 & & & 0.738 & DK28 & & & 0.516 \\
\hline DK1 & & & 0.730 & DK12 & & & 0.504 \\
\hline DK5 & & & 0.728 & DK4 & & & 0.446 \\
\hline DK6 & & & 0.720 & Faktör 9 & 1.441 & 2.089 & \\
\hline DK8 & & & 0.519 & DK59 & & & 0.647 \\
\hline Faktör 6 & 1.957 & 2.836 & & DK10 & & & 0.449 \\
\hline DK31 & & & 0.616 & Faktör 10 & 1.282 & 1.858 & \\
\hline DK29 & & & 0.589 & DK33 & & & 0.655 \\
\hline DK32 & & & 0.558 & DK62 & & & 0.536 \\
\hline DK30 & & & 0.554 & Faktör 11 & 1.217 & 1.764 & \\
\hline DK35 & & & 0.475 & DK13 & & & 0.596 \\
\hline DK44 & & & 0.371 & DK14 & & & 0.495 \\
\hline Faktör 7 & 1.799 & 2.607 & & Faktör 12 & 1.166 & 1.663 & \\
\hline DK69 & & & 0.769 & DK61 & & & 0.750 \\
\hline DK68 & & & 0.746 & DK3 & & & 0.473 \\
\hline DK67 & & & 0.736 & & & & \\
\hline DK65 & & & 0.566 & & & & \\
\hline
\end{tabular}

Tablo 5'de inşaat mühendislerini demotive eden kriterlerle ilgili değişkenlere uygulanan faktör analizi sonucunda, toplam on iki adet demotivasyon faktörü ortaya çıkmıştır. Analizin Kaiser-Meyer-Olkin (KMO) test değeri \%82.5 (0.825)'dir. KMO değerinin $0,5^{\prime}$ in üzerinde olması gerekmektedir. $0.825>0.500$ olduğu için veri setinin faktör analizi için uygun olduğu söylenebilir. Faktör analizinin ikinci basamağı olan Bartlett testi değerleri $\chi^{2}=6655.442(\mathrm{p}<0.000)$ olarak elde edilmiştir. $\mathrm{Bu}$ değerlere göre, değişkenler arasında yüksek korelasyon mevcuttur, başka bir ifade ile veri seti faktör analizi için uygundur. Faktör sayısının belirlenmesinde Öz değer (Eigen value) yöntemi kullanılmıştır. Bu yöntemde faktörün geçerli olarak kabul edilebilmesi için öz değerin bir ve birden büyük olması kriteri aranmıştır Öz değer istatistiği 1'den büyük olan on iki 
faktör belirlenmiştir. Birinci faktör toplam varyansın \%29.602' sini açıklamaktadır. On iki faktör ise toplam varyansın \% 70.44 'ünü açıklamaktadır.

İnşaat mühendislerini demotive eden faktör yükleri, varyans yüzdeleri, öz değerler ve faktör isimleri Tablo 5'de görülmektedir. Faktörlerin isimlendirilme aşamasında ise bir faktör altında büyük ağırlıkları olan değişkenleri gruplamak gerekir [28].

Birinci faktör toplam varyansın en yüksek değerine sahiptir (\%42.901) ve on bir adet demotivasyon kriteri içermektedir. $\mathrm{Bu}$ faktör altında toplanan kriterlerin içeriği incelendiğinde bu faktör "Yönetici ve çalışma ekibi arasındaki ilişki kaynaklı demotivasyon faktörü" olarak isimlendirilmiștir.

İkinci demotivasyon faktörü toplam varyansın \%4.532'sini açılamakta ve dokuz adet kriter içermektedir. Faktöre yüklenen kriterlerin içeriği incelendiğinde faktör "Proje kaynaklı stres ve müşteri kaynaklı demotivasyon faktörü” olarak isimlendirilmiştir.

Üçüncü faktör varyansın \%4.288'ini açıklamakta ve on adet kriter içermektedir. Bu faktöre yüklenen kriterlerin içeriği incelendiğinde ise faktörün "Kariyer gelişimi imkânlarının yetersizliği ve zayıf örgütsel kültür kaynakl demotivasyon faktörü” olarak isimlendirilmesi uygun bulunmuştur.

Varyansın \%3.563'ünü açıklamakta ve on bir adet kriter içeren dördüncü faktör "Ödemelerdeki adaletsizlik, takdir edilmeme ve aşırı iş yükü kaynakl demotivasyon faktörü” olarak isimlendirilmiştir.

\%3.176'lık bir bölümü açıklayan ve altı adet kriter içeren beşinci faktör "Çalışma ekibi üyelerinin zaylf iş ilişkileri ve iletişim eksikliği kaynaklı demotivasyon faktörü" olarak isimlendirilmiştir.

Altı adet demotivasyon kriteri içeren ve ve varyansın \%2.836'lık bölümünü açıklayan altıncı faktör "Kötü çalışma koşulları ve aidiyet hissi eksikliği kaynaklı demotivasyon faktörü" olarak adlandırılmıştır.

Yedinci faktör dört adet demotivasyon kriteri içermekte ve varyansın \%2.607'lik bir bölümünü açıklamaktadır. Bu faktör "Uzak mesafeler ve iş yerine ulaşım sorunu kaynaklı demotivasyon faktörü” olarak isimlendirilmiştir.

Sekizinci faktör dört adet kriter içermekte ve varyansın \%2.341'lik dilimini açıklamaktadır. Faktör altında gruplanan kriterlerin içeriği incelenerek faktör " Cinsiyet ayrımı ve aşırı rekabet kaynaklı demotivasyon faktörü” olarak isimlendirilmiştir.

Dokuz, on, on bir ve on ikinci faktörler altında ikişer adet kriter gruplanmış olup, sirasiyla toplam varyansın $\% 2.089, \% 1.858, \% 1.764$ ve $\% 1.663$ 'lük bölümünü açıklamaktadırlar. Faktörler altında gruplanan kriterlerin içeriği incelendiğinde dokuzuncu faktör "Yasal mevzuat kısıtlamaları ve ekip üyeleri arasındaki dinamizm eksikliği kaynaklı demotivasyon faktörü"; onuncu faktör "Hizmet içi eğitim yetersizliği ve dönemsel iş dengesizliği kaynakl demotivasyon faktörü"; on birinci faktör "Organizasyonun sosyal uğraş yetersizliği kaynakl demotivasyon faktörü"; ve son faktör ise "Başarısızlık ve farklı özelliklerdeki ekip üyeleri kaynakl demotivasyon faktörü” olarak isimlendirilmiştir. 


\section{Sonuçlar ve öneriler}

Bu çalışmada yapı üretim sürecinde önemli rol oynayan inşaat mühendislerini demotive eden kriterlerin belirlenmesi ve demotivasyon kriterleri ile cinsiyet, medeni durum, görev pozisyonu ve yaş değişkenleri arasındaki ilişkilerin incelenmesi amaçlanıp, özel sektörde çalışan inşaat mühendislerini demotive eden faktörlerin belirlenmesi hedeflenmiştir. Bu kapsamda hazırlanan anket formu ile 118 adet inşaat mühendislinden veri toplanmıştır. Elde edilen veriler ile yapılan analizler sonucunda;

Özel sektörde çalışan inşaat mühendislerinin cinsiyeti ile demotivasyon kriterlerinin yirmi beşi arasında anlamlı ilişki tespit edilmiştir. Aralarında ilişki belirlenen her bir demotivasyon kriterinin kadın inşaat mühendislerini erkeklerden daha çok etkilediği belirlenmiştir. Bu durumun nedeninin kadınların çevresel etkenlerden erkeklere oranla daha fazla etkilenmelerinin olabileceği düşünülmektedir. Bu nedenle karşılaştıkları olumsuzluklarda erkeklere oranla daha fazla demotive olabilmektedirler.

İnşaat mühendislerinin medeni durumları ile demotivasyon kriterlerinin yedi adedi ile arasında anlamlı ilişki olduğu belirlenmiştir. Çalışma arkadaşları arasındaki rekabet, hizmet içi eğitim ve kariyer geliştirme imkanlarının yetersizliği gibi konuları bekar mühendisler evli olanlara göre daha fazla önemsemektedirler. Bunun nedeninin, henüz evlenmemiş olan inşaat mühendislerinin geleceklerine yatırım yapabilme kaygısı ve kariyer geliştirme kaygılardan kaynaklandığ 1 düşünülmektedir. İşlerdeki başarısızlık oranının yüksek olması ve firmaya gelen işlerin yıl içinde dengeli bir dağılım göstermemesi kriterleri evli olan mühendisleri bekar olanlara oranla daha çok demotive etmektedirler. $\mathrm{Bu}$ durumun nedeninin ise, evli olan bireylerin kendileri kadar aile bireylerinin geçimi ve geleceğini düşünerek birden fazla kişinin sorumluluğunu taşımaları olabileceği düşünülmektedir.

Görev pozisyonu ile demotivasyon kriterlerinin büyük çoğunluğu arasında anlamlı ilişki bulunmuştur ve aralarında ilişki belirlenen her bir demotivasyon kriterinin çalışan pozisyonundaki inşaat mühendislerini yönetici pozisyonundakilere göre daha çok etkilediği belirlenmiştir. Bunun durumun olası nedenlerinin çalışan pozisyonundaki inşaat mühendislerinin işlerini kaybetme korkusunun yönetici pozisyonundakilere göre daha fazla olması; emir-komuta zincirinde alt kademede bulunan çalışanların streslerinin daha fazla olması; çalışma saatlerin yöneticilere kıyasla daha az esnek olması ve daha az gelirlerinin olması olduğu düşünülmektedir.

İnşaat mühendislerinin yaşı ile hiçbir demotivasyon kriteri arasında anlamlı bir ilişkiye rastlanmamıştır.

Özel sektörde çalışan inşaat mühendislerini en çok demotive eden kriter, aynı görev pozisyonunda çalışanların maaşlarının eşit ve adaletli olmaması iken en az demotive eden kriter, çok farklı kültürden insanların bir arada çalışması olarak belirlenmiştir.

Özel sektörde çalışan inşaat mühendislerini demotive eden faktörler ise;

- Yönetici ve çalışma ekibi arasındaki ilişki kaynaklı demotivasyon faktörü

- Proje kaynaklı stres ve müşteri kaynaklı demotivasyon faktörü

- Kariyer gelişimi imkânlarının yetersizliği ve zayıf örgütsel kültür kaynaklı demotivasyon faktörü 
- Ödemelerdeki adaletsizlik, takdir edilmeme ve aşırı iş yükü kaynaklı demotivasyon faktörü

- Çalışma ekibi üyelerinin zayıf iş ilişkileri ve iletişim eksikliği kaynaklı demotivasyon faktörü

- Kötü çalışma koşulları ve aidiyet hissi eksikliği kaynaklı demotivasyon faktörleri

- Uzak mesafeler ve iş yerine ulaşım sorunu kaynaklı demotivasyon faktörü

- Cinsiyet ayrımı ve aşırı rekabet kaynaklı demotivasyon faktörü

- Yasal mevzuat kısıtlamaları ve ekip üyeleri arasındaki dinamizm eksikliği kaynaklı demotivasyon faktörü

- Hizmet içi eğitim yetersizliğgi ve dönemsel iş dengesizliği kaynaklı demotivasyon faktörü

- Organizasyonun sosyal uğraş yetersizliği kaynaklı demotivasyon faktörü

- Başarısızlık ve farklı özelliklerdeki ekip üyeleri kaynaklı demotivasyon faktörü olarak belirlenmiştir.

İnşaat mühendislerini demotive eden faktörlerin belirlenmesi ile ilgili literatürde herhangi bir çalışmaya rastlanmamış olması nedeniyle bu çalışma ile literatüre bir katkı sağlanacağı düşünülmektedir. Ayrıca kamu sektöründe çalışan inşaat mühendislerini demotive eden faktörlerin araştırılması, örneklem büyüklüğünün artırılması, gelecekte yapılacak olan çalışmalarda araştırma konusu olabilir.

\section{Kaynaklar}

[1] Ritchie, S. ve Martin, P., Motivation management. Gower Publishing, Aldershot (1999).

[2] Gorham, J. ve Christophel, D.M., Students' Perception of Teacher Behaviors as Motivating and Demotivating Factors in College Classes. Communication Quarterly 40, 3, 239-252, (1992).

[3] Ng, S.T., Skitmore, M.R., Lam, K.C. ve Poon, A.W.C., Demotivating Factors Influencing the Productivity of Civil Engineering Projects, International Journal of Project Management, 22, 139-146, (2004).

[4] Maslow, A.H., A Theory of Human Motivation, Psychological Review, 50, 4, 370-396, (1943).

[5] Schrader, C.R., Motivating Construction Craftsmen, Journal of the Construction Division, 98, CO2, 257-273, (1972).

[6] Borcherding, J.D., Motivating the Lower Level Supervisory Staff and Work Force on Super Projects, Project Management Institute Proceedings, Ninth Annual Seminar/ Symposium, 237-248, (1977).

[7] Laufer, A ve Jenkins, G.D., Motivating Construction Workers, Journal of the Construction Division, 108, CO4, 531-545, (1983).

[8] Olomolaiye, P.O. and Price, A.D., A Review of Construction Operative Motivation, Building Environment, 24, 3, 279-287, (1989).

[9] Moilwa, T and Langford, D. A., The Motivation of Construction Supervisors in Botswana, Journal of Habitat International, 14(2/3) 193-204, (1990).

[10] Kaming, P., Olomolaiye, P.O., Holt, G.D., Harris, F.C., What Motivates Construction Craftsmen in Developing Countries? A Case Study of Indonesia, Building and Environment, 33, 2-3, 131-141, (1998). 
[11] Doloi, H., Twinning Motivation, Productivity and Management Strategy in Construction Projects, Journal of Engineering Management, 19, 3, 30-40, (2007).

[12] Kazaz, A., Manisali, E., Ulubeyli, S., Effect of Basic Motivational Factors on Construction Workforce Productivity in Turkey, Journal of Civil Engineering and Management, 14, 2, 95-106, (2008).

[13] Oyedele, L.O., Analysis of Architects' Demotivating Factors in Design Firms, International Journal of Project Management, 31, 342-354, (2013).

[14] Çivici, T., Mimari Tasarım Bürolarında Çalışan Mimarların Mesleki Tükenmişlik Düzeylerini Etkileyen Demotivasyon Faktörleri, Çukurova Üniversitesi Mühendislik Mimarlık Fakültesi Dergisi, 31, 1, 281-292, (2016).

[15] Pfeffer, J., Competitive Advantage Though People. Harvard Business School Press, Boston, Massachusetts, (1994).

[16] Amabile, T.M., Motivational Synergy: Toward New Conceptualizations of Intrinsic and Extrinsic Motivation in the Workplace. Human Resource Management Review, 3, 3, 185-201, (1993).

[17] Falout, J., Elwood, J., Hood, M., Demotivation: Affective States and Learning Outcomes, System 37, 3, 403-417, (2009).

[18] İnşaat Sektörü Raporu Intes Türkiye İnşaat Sanayicileri İşveren Sendikas1, http://intes.org.tr/content/insaat_2016.pdf (2016).

[19] Öğrüç Ildız G., Proje Yönetimi: İnşaat Firmalarında Proje Müdürlerinin İş Yükü, İş Stresi, İş Tatmini ve Motivasyon İlişkisi, İstanbul Kültür Üniversitesi, Fen Bilimleri Enstitüsü, İnşaat Mühendisliği Anabilim Dalı, Yüksek Lisans Tezi, İstanbul, (2009).

[20] Akat, İ. ve Budak, G., İșletme Yönetimi, Beta Yayınları, İstanbul, (1994).

[21] Sabuncuoğlu, Z. ve Tüz, M., Örgütsel Psikoloji, Furkan Ofset, Bursa, (2003).

[22] Sapancalı, F., Çalışanların Güdülenmesinde Kullanılan Özendirici Araçlar, Verimlilik Dergisi, MPM Yayınları, 22, 4, 55-74, (1993).

[23] Rhoades, L. ve Eisenberger, R., Perceived Organizational Support: A Review of the Literature. Journal of Applied Psychology, 87, 3, 565-573, (2002).

[24] Luthans, F., Organizational Behavior, 6th Edition. New York: McGraw-Hill, (1992).

[25] Y1lmaz, M.K., Stres ve Motivasyonun Satış Gücünün İş Tatmini Üzerine Etkisi:Erzurum'daki İlaç Satış Mümessilleri Üzerinde Bir Uygulama, Yüksek Lisans Tezi, Atatürk Üniversitesi Sosyal Bilimler Enstitüsü, İşletme Anabilim Dal1, Erzurum, (2006).

[26] Wong, S. ve Pang, L., Motivators to Creativity in the Hotel Industry Perspectives of Managers and Supervisors, Tourism Management, 24, 5, 551559, (2003).

[27] Fındıkçı, İ., İnsan Kaynakları Yönetimi, Alfa Yayınları, İstanbul, (2000).

[28] Kalaycı, E., SPSS Uygulamalı Çok Değişkenli İstatistik Teknikleri. 3. Bask1, Asil Yayın Dağıtım, Ankara, (2008).

[29] Özdamar, K., Paket Programlar ile İstatistiksel Veri Analizi-1, 9. Bask1, Nisan Kitabevi, Eskişehir.

[30] Chan, D.M.W. ve Kumaraswamy, M.M., Compressing Construction Durations: Lessons Learned from Hong Kong Building Projects, International Journal of Project Management, 20, 1, 23-35, (2002). 